ISTIGHNA, Vol. 3, No 2, Juli 2020 P-ISSN 1979-2824 E-ISSN 2655-8459

Homepage: http://e-journal.stit-islamic-village.ac.id/index.php/istighna

Deden Saeful Ridhwan, Novri Dewita

Pendidikan Nahdlatul Ulama untuk Peradaban Dunia

(Respon K.H. Abdul Wahid Hasyim)

\title{
PENDIDIKAN NAHDLATUL ULAMA UNTUK PERADABAN DUNIA (RESPON K.H. ABDUL WAHID HASYIM)
}

\author{
Deden Saeful Ridhwan \\ dedensaefulridhwan.stit@gmail.com \\ Program Studi PAI STIT Islamic Village Tangerang - Indonesia \\ Novri Dewita \\ Madrayah Aliyah Nurul Falah Cililin Bandung Barat- Indonesia
}

\begin{abstract}
Kiayi Wahid Hasyim, a reformist pro-change, proposed changes and at the same time did the same for the pesantren environment. The most monumental changes in Pondok Pesantren Tebuireng, reforms in the methods and objectives of learning at the pesantren, and the establishment of madrasas. Kiayi Wahid Hasyim made the system tutorial as a bandongan method session. According to him, the bandongan method is very ineffective for the initiative of the students. Few things are aware that Kiayi Wahid Hasyim is a traditionalist who claims to be futuristic. $\mathrm{He}$ is a figure who represents circles that are rarely touched by academics, even researchers, most of whom are Western researchers, who tend to fall in love with modernists who are dynamic, adaptive, pragmatic, and not at all hostile to those from the West.
\end{abstract}

Keywords: Pesantren, Islamic Education Reform

\begin{abstract}
Abstrak: Kiayi Wahid Hasyim seorang reformis properubahan, ia mengajukan perubahan sekaligus melakukan yang sama sekali bagi lingkungan pesantren. Perubahan paling monumental di Pondok Pesantren Tebuireng, pembaruan pembaharuan dalam metode dan tujuan belajar di pesantren dan pendirian madrasah. Kiayi Wahid Hasyim menjadikan tutorial sistem sebagai sesi metode bandongan. Menurutnya metode bandongan sangat tidak efektif untuk inisiatif para santri. Sedikit hal yang menyadari bahwa Kiayi Wahid Hasyim seorang tradionalis yang menyatakan futuristik. Ia adalah sosok yang mewakili kalangan yang jarang sekali tersentuh oleh para akademisi bahkan peneliti sekalipun, yang kebanyakan peneliti terutama peneliti Barat, cenderung jatuh hati pada kelompok modernis yang dinamis, adaptif, pragmatis, dan sama sekali tidak bermusuhan dengan yang berasal dari kawasan Barat.
\end{abstract}

Kata Kunci: Pesantren, Pembaharuan Pendidikan Islam

Peer reviewed under reponsibility of STIT ISLAMIC VILLAGE.

(C) 2018 STIT ISLAMIC VILLAGE, All right reserved, This is an open access article under 214 the CC BY SA license (https://creativecommons.org/licenses/by-sa/4.0/) 
ISTIGHNA, Vol. 3, No 2, Juli 2020 P-ISSN 1979-2824

Homepage: http://e-journal.stit-islamic-village.ac.id/index.php/istighna

Deden Saeful Ridhwan, Novri Dewita

Pendidikan Nahdlatul Ulama untuk Peradaban Dunia

(Respon K.H. Abdul Wahid Hasyim)

\section{A. PENDAHULUAN}

\section{Latar Belakang}

Pendidikan merupakan sarana yang sangat penting dalam menuangkan dan menggali potensi yang ada dalam diri manusia, baik dalam proses perbaikan, penguatan dan penyempurnaan terhadap semua kemampuan yang ada dalam diri manusia. ${ }^{1}$ Dengan demikian pendidikan merupakan sebuah usaha yang dilakukan agar manusia dapat mengembangkan potensi yang terdapat didalam dirirnya melalui sebuah proses pembelajaran. Berdasarkan undang-undang dasar Negara Republik Indosnesia Tahun 1945 pasar 31 ayat (1) menyebutkan bahwa setiap warga negara berhak mendapat pendidikan dalam rangka mencerdaskan kehidupan Bangsa yang diatur dengan undang-undang. Untuk itu seluruh komponen bangsa mempunyai kewajiban mencerdaskan kehidupan bangsa yang merupakan salah satu dari tujuan Negara Indonesia. ${ }^{2}$

Pendidikan Islam adalah usaha yang dilakukan untuk mengembangkan seluruh potensi manusia baik lahir maupun batin agar terbentuknya pribadi Muslim seutuhnya. ${ }^{3}$ Pendidikan Islam senantiasa menjadi kajian yang menarik bukan hanya karena memiliki kekhasan ${ }^{4}$ tersendiri dibanding jenis pendidikan umum, namun juga karena kaya akan konsep-konsep yang tidak kalah bermutu dibandingkan dengan pendidikan modern. ${ }^{5}$

${ }^{1}$ Deden Saeful Ridhwan, Madrasah di Indonesia, Dinamika dan Eksistensinya (Jakarta: Jurnal Ma'arif NU, 2017), Edisi XV. Tahun 2017. h. 40.

${ }^{2}$ Undang-undang RI No 20 Tahun 2003 tentang Sistem Pendidikan Nasional (Bandung: Citra Umbara, 2016), h. 48

${ }^{3}$ Haidar Putra Daulay, Pendidikan Islam dalam Perspektif Filsafat (Jakarta: Kharisma Putra Utama, 2014), h. 11

4 "Karakter khas", Pendidikan Pesantren yang telah mengajarkan cara beragama yang toleran (tasammuh), moderat (tawassuth), dan berkeseimbangan (tawa>zun) yang membentuk karakter khas Islam di Indonesia yang sering kita sebut dengan "Islam Nusantara". Model Pendidikan Islam yang damai, tanpa kekerasan, yang mengajarkan keteladanan, toleransi, mengenal satu sama lain, dan menghargai perbedaan telah memberikan sumbangan besar dalam pembentukan karakter bangsa Indonesia. Lihat, Lukman Hakim Saifuddin, Kekhasan Pendidikan Islam (Jakarta: Direktorat Jenderal Pendidikan Islam Kemterian Agama RI, 2015), h. ix. Berkaitan dengan hal tersebut tanggal 21-3-2017. Tajuk Kompas memuat ungkapan "Kembali ke Jalur Moderat" Tulisan tersebut meng follow up dan menginformasikan pesan dari "Risalah Sarang". Yakni Lima poin yang dihasilkan dari pertemuan ulama-ulama kharismatik $(k h a>s)$ di Sarang Rembang Jawa Tengah. Kerangka yang ingin dibangun dari "Risalah Sarang" tersebut yakni pentingnya kembali untuk berprilaku moderat, toleran, demokratis, dan selalu mengedepankan akhlak al-Karimah. A. Helmy Faisal Zaini, Nasionalisme Kaum Sarungan (Jakarta: Kompas, 2018), h. 54. Lihat juga, Azyumardi Azra, dalam Nurcholis Madjid, Bilik-bilik Pesantren sebuah Potret Perjalanan (Jakarta: Paramadina, 1997), h. xxi. Baca juga, A Musthofa Haroen, Meneguhkan Islam Nusantara, Biografi Pemikiran dan Kiprah Kebangsaan Prof. Dr. KH. Said Aqil Siroj, MA. (Jakarta: Khalista, 2015), h. 111.

5 Abdurrahman Mas'ud, Pengantar dalam Ruchman Basori, The Founding Father Pesantren Modern Indonesia Jejek Langkah KH.A. Wahid Hasyim (Jakarta: Inceis, 2008), h. v. 
ISTIGHNA, Vol. 3, No 2, Juli 2020 P-ISSN 1979-2824

Homepage: http://e-journal.stit-islamic-village.ac.id/index.php/istighna

Deden Saeful Ridhwan, Novri Dewita

Pendidikan Nahdlatul Ulama untuk Peradaban Dunia

(Respon K.H. Abdul Wahid Hasyim)

Dalam perkembangannya, dunia pendidikan tentu tidak akan terlepas dari kontribusi para ilmuan yang mencurahkan segala perhatiannya. Perubahan dan perkembangan serta kontribusi institusi pendidikan Islam di kalangan kaum tradisional hampir tidak pernah tersentuh, ${ }^{6}$ meskipun banyak ditemukan institusi dan tokoh yang representative dari kalangan tradisionalis berkontribusi terhadap Republik ini. ${ }^{7}$ Adapun sosok nama yang selalu harum berkaitan dengan pembaharuan pendidikan di kalangan tradisionalis adalah Kiayi Abdul Wahid Hasyim. ${ }^{8}$ Seorang pemimpin teras Nahdlatul Ulama, dan seorang yang mempunyai kepedulian yang tinggi terhadap pendidikan kaum muslimin di Idonesia khususnya dari kalangan kelompok tradisional.

Kiayi Abdul Wahid Hasyim telah dikenal sebagai seorang figure mata rantai yang menjabat peradaban pesantren dengan peradaban Islam modern. Kiayi Abdul Wahid Hasyim merupakan sosok yang sangat berpengaruh dan keberadaannya membawa dampak yang sangat besar dalam mengarahkan bangsa Indonesia menuju peradaban yang lebih mapan. Dari uraian di atas, penulis mencoba untuk menelaah respon Kiayi Abdul Wahid Hasyim dalam Pembaharuan Pendidikan Islam terkhusus di Pesantren dan Madrasah. Telaahan dalam tulisan ini akan berfokus pada masalah sebagai berikut: Bagaimana latar belakang Iintelektual K.H. Abdul Wahid Hasyim?. Bagaimana karya intelektualnya?. Serta bagaimama Pembaharuan yang dilakukannya?.

\section{Biografi Kiayi Wahid Hasyim}

Kiayi Abdul Wahid Hasyim (selanjutnya ditulis Kiayi Wahid Hasyim) adalah sosok pengembara intelektual di berbagai pesantren di tanah air sampai ke tanah suci Makkah sehingga menjadikan pikiran dan gerak langkahnya dinamis dan

${ }^{6}$ Tradisional adalah sikap, cara berpikir, dan bertindak yang selalu berpegang pada norma dan adat kebiasaan secara turun temurun. Lihat, Tim Penyusun Kamus Besar Bahasa Indonesia, Kamus Besar Bahasa Indonesia (Jakarta: Balai Pustaka, 1988), h. 959. Istilah ini biasanya digunakan untuk menunjuk orang atau sekelompok orang yang masih berpegang teguh pada tradisi. Lihat, Rumadi, Post Tradisionalisme Islam Wacana Intelektualisme dalam Komunitas NU (Jakarta: Departemen Agama RI, 2007), h. 10. Fachri Ali mengontraskan tradisionalis dengan medernis, lihat, Fachry Ali dan Bakhtiar Effendy, Merambah Jalan Baru Islam, Rekonstruksi Pemikiran Islam Indonesia Masa Orde Baru (Bandung: Mizan, 1990), h. 48. Bandingkan dengan, Bambang Pranowo, Runtuhnya Dikotomi Santri-Abangan, Refleksi Sosiologis atas Perkembangan Islam di Jawa Pasca 1965. Dalam Pidato Pengukuhan Guru Besar dalam Ilmu Sosiologi Agama pada Fakultas Ushuluddin IAIN Syarif Hidayatullah Jakarta (Jakarta: IAIN, 2001), h. 10.

7 Azyumardi Azra, Pendidikan Islam Tradisi dan Modernisasi Menuju Milenium Baru (Jakarta: Kalimah, 2001), h. 70.

${ }^{8}$ Zamakhsyari Dhofier, Tradisi Pesantren. Studi Pandangan Hidup Kiayi dan Visinya Mengenai Masa Depan Indonesia (Jakarta: LP3ES, 2011). h. 149. 
ISTIGHNA, Vol. 3, No 2, Juli 2020 P-ISSN 1979-2824

Homepage: http://e-journal.stit-islamic-village.ac.id/index.php/istighna

Deden Saeful Ridhwan, Novri Dewita Pendidikan Nahdlatul Ulama untuk Peradaban Dunia

(Respon K.H. Abdul Wahid Hasyim)

progresif, terasa manfaatnya yang dirasakan oleh masyarakat Indonesia. Beliau juga sosok penghubung antara peradaban pesantren dan Indonesia modern. ${ }^{9}$

Kiayi Wahid Hasyim, yang akrab disapa dengan Gus Wahid, lahir pada hari jum 'at legi, tanggal 5 Rabi> ul Awal 1333 H, bertepatan dengan 1 Juni 1914 di Desa Tebuireng, Jombang, Jawa Timur. Oleh ayahnya, Hadratussyaikh K.H. Hasyim Asy'ari beliau diberi nama Muhammad Asy'ari, terambil dari nama kakeknya. Konon nama itu tidak serasi atau terasa berat, maka namanya diganti dengan Abdul Wahid. Namun ibunya kerap kali memanggil dengan nama Mudin, sedangkan kemenakannya yang masih kecil-kecil sering menyebut dengan Pak It. Sedangkan para santri dan masyarakat sekitar sering memanggil dengan Gus Wahid. ${ }^{10}$ Sebagai panggilan yang kerap ditujukan untuk menyebut putra seorang Kyai di tanah Jawa.

Keluarga besar Pesantren Tebuireng menyambut suka cinta atas kelahiran Wahid Hasyim. Suatu kebahagiaan yang amat besar, bayi yang rupawan itu adalah laki-laki pertama, setelah sebelumnya dianugrahi empat orang putri yaitu: Abdullah (meninggal masih kecil), Hanah, Ummu Abd. Jabar, Ummu Muhammad dan Ummu Abd. Haq. Jadi keempat kakak Wahid Hasyim yang masih hidup waktu beliau lahir adalah perempuan, sedangkan kakak pertamanya yang laki-laki meninggal waktu lahir. Wahid Hasyim adalah anak kelima yang masih hidup. Sedangkan adiknya ada sembilan orang yaitu: (1) Abd. Hafiz , (2) Abd. Karim, (3) Ubaidillah, (4) Masruroh, (5) Yusuf, (6) Abdil Kadir, (7) Fatimah, (8) Khadijah, dan (9) A. Ya'qub. Dari kesepuluh putra Hasyim Asy'ari yang masih hidup adalah tinggal tiga orang, yaitu Yusuf Hasyim dan kedua adiknya yaitu Fatimah dan A. Ya'qub. ${ }^{11}$

Ketika mengandung Wahid Hasyim, kandungan ibunya sangat lemah, tubuhnya lemas, gelisah, dan sakit-sakitan. Lalu ibunya bernadzar, kalau bayi itu lahir dan selamat maka ia akan mendatangi guru ayahnya, yaitu KH. Kholil Bangkalan, Madura. Singkat cerita lahirlah bayi tersebut dan dipenuhilah nadzar sang ibu, waktu Wahid Hasyim berusia tiga bulan. Dikisahkan bahwa dari Tebuireng ke Bangkalan. Nyai Hasyim Asy'ari menempuh perjalanan dengan kereta, yang waktu itu penuh sesak dengan pedagang-pedagang yang pulang dari Surabaya pada sore hari. Ditemani Mbah Abu, Nyai Hasyim menempuh perjalanan

9 Zamakhsyari Dhofier, Tradisi Pesantren Studi Pandangan Hidup Kyai dan Visinya Mengenai Masa Depan Indonesia, h. 151. Lihat juga, Zamakhsyari Dhofier, K.H. A. Wahid Hasyim Rantai Penghubung Peradaban Pesantren dengan Peradaban Indonesia Modern (Jakarta: Prisma No. 8, 1984), h. 73

${ }^{10}$ Seri Buku Tempo, Wahid Hasyim untuk Republik dari Tebuirang (Jakarta: KPG, 2011), h. 11 .

${ }^{11}$ Ruchman Basori, The Founding Father Pesantren Modern Indonesia Jejak Langkah KH. A. Wahid Hasyim (Jakarta: Incies, 2008), h. 58 
ISTIGHNA, Vol. 3, No 2, Juli 2020 P-ISSN 1979-2824

Homepage: http://e-journal.stit-islamic-village.ac.id/index.php/istighna

Deden Saeful Ridhwan, Novri Dewita Pendidikan Nahdlatul Ulama untuk Peradaban Dunia

(Respon K.H. Abdul Wahid Hasyim)

yang berat, karena pada waktu mereka turun dari kereta api, hari sudah siang dan udara kelihatannya agak mendung. Ibu yang menggendong anak dengan tergesagesa mencari sebuah andong/dokar/delman, yang dapat membawanya ke desa Kademangan, yang letaknya masih jauh.

Sesampai di Kademangan, dengan berjalan kaki yang berjarak cukup jauh untuk mencapai tempat di mana Mbah Kholil tinggal, yaitu di sebuah pondok yang sangat sederhana di kelilingi pekarangan sebagai dinding, hari mulai sudah malam dan hujan sudah mulai turun rintik-rintik. Kemudian beberapa kali Nyai Hasyim Asy'ari memohon izin masuk dengan logat Madura "pangapora non", namun tak ada yang menyahut, beberapa lama kemudian, muncul dari rumah seseorang, berjangkut panjang yang sudah memutih. Mungkim itulah Kyai Kholil yang menjadi tujuan Nyai Hasyim Asy'ari yang sudah menempuh perjalanan yang cukup jauh. Kyai berkata dalam bahasa Madura yang artinya: "Kamu tidak diizinkan masuk ke rumah saya, dan tidak pula saya izinkan pergi dari situ, pendek kata, kamu harus tetap berada dalam tempatmu itu sekarang, sampai ada perintah lagi dari saya."

Patuh dan taat serta rasa takut kepada orang itu, Nyai Hasyim Asy'ari tidak bergeser sedikitpun dari tempatnya, meskipun hujan sudah mulai turun dan Nyai Hasyim pun telah basah kuyup. Karena hujan makin besar, suara petir sudah sambung-menyambung, maka kedua perempuan itu beralih berlindung ke bawah atap rumah itu dan membersihkan diri meletakkan bayi itu di atas beranda muka, sambil membaca lafad: La> Ilaha Illa Anta, ya hayyu ya qayyu>m.

Namun sang Kyai tidak mengizinkan bayi itu ditaruh di bawah lindungan atap rumahnya dan harus diambil kembali dan dibawa ketengah halaman yang dalam keadaan hujan lebat itu. Nyai Hasyim tidak membantah sedikitpun, seolah-olah ada kekuatan gaib yang menggerakkan dia berdiri dan pergi mengambil anak bayinya di atas lantai dengan hati yang tetap penuh keikhlasan dan tawakal. Bayi diletakan kembali dalam pangkuannya, dan dilindunginya dari air hujan yang cukup lebat. Akhirnya Mbah Kholil meminta Ny. Nafiqoh untuk meninggalkan tempat, dan tidak ada pilihan lain akhirnya pulang ke Jombang dengan seribu tanda tanya yang tak terjawab ketika itu. Rupanya kejadian di luar kebiasaan itu menjadi salah satu pertanda bahwa Abdul Wahid kelak akan menjadi orang yang tergolong luar biasa. Ternyata hal itu terbukti di kelak kemudian hari. Ada juga yang mengkaitkan bahwa kejadian tersebut dengan kematian Wahid Hasyim, ketika kecelakaan di Cimahi, Jawa Barat pada tahun 1953. 
ISTIGHNA, Vol. 3, No 2, Juli 2020 P-ISSN 1979-2824

Homepage: http://e-journal.stit-islamic-village.ac.id/index.php/istighna

Deden Saeful Ridhwan, Novri Dewita Pendidikan Nahdlatul Ulama untuk Peradaban Dunia

(Respon K.H. Abdul Wahid Hasyim)

Dilihat dari garis keturunan Wahid Hasyim, baik dari garis Ayah, Hadratus Syaikh Hasyim Asy'ari maupun ibu, Nyai Nafiqoh, sama-sama keturunan Lembupeteng (Brawaijaya ke VI). Dari pihak ayah melalui Djoko Tingkir dan garis ibu melalui Kyai Ageng Tarub. ${ }^{13}$

Wahid kecil dalam usia lima tahun sudah belajar membaca al-Qur'an. Untuk pengetahuan agama, Wahid belajar di pesantren Tebuireng pada pagi hari. Karena cepatnya ia menyerap ilmu yang diajarkan, pada usia tujuh tahun ia sudah mulai belajar "kitab". Di antaranya kitab Fathul Qari>b, Minha>jul Qawi>m, dan kitab Mutammimah $^{14}$ pada ayahnya juga. Pada tahun 1926, ketika berusia dua belas tahun, Wahid Hasyim telah menamatkan studinya di Madrasah Salafiah Tebuireng. Pada saat itu pula ia mulai mengajarkan adiknya (A. Karim Hasyim) kitab 'Izi di malam hari. Pada saat itu, beliau telah mulai senang menekuni pelajaran bahasa Arab dan tertarik membaca buku-buku secara luas.

Wahid Hasyim juga menyerap ilmu dari pesantren di luar Tebuireng, antara lain, pernah belajar di Pondok pesantren Siwalan, Panji, Sidoarjo, juga Pesantren Lirboyo, Kediri. Pesantren ini dibangun teman ayahnya, Kyai Abdul Karim. Ia hanya tiga hari berada di pesantren ini. Dari Lirboyo, Wahid meneruskan pengembaraan ke sejumlah pesantren yang ada di sekitar Jawa Timur. Selama dua tahun ia berpindah-pindah pesantren, kemudian pulang ke Tebuireng.

Mondok perpindah-pindah merupakan tradisi nahdliyin. "para santri sering berkeliaran untuk mencari barokah sang Kyai". Dengan berpindah-pindah pondok dan nyantri hanya dalam hitungan hari itu seolah-olah yang diperlukan Wahid Hasyim adalah keberkahan dari sang guru, bukan ilmunya itu sendiri. Soal ilmu, demikian mungkin dia berpikir, bisa dipelajari di mana saja dan dengan cara bagaimana saja. Tapi soal memperoleh berkah dari kyai harus dilakukan dengan sungguh-sungguh dan menetapkan di pesantren. Inilah yang agaknya menjadi pertimbangan utama dari Wahid Hasyim ketika itu. ${ }^{15}$

Ketika menginjak usia 17 tahun (1932-1933), beliau dikirim ayahnya belajar selama 1 tahun di Makkah di samping untuk menunaikan ibadaah haji dengan ditemani Moh. Ilyas, sepupunya yang telah banyak berjasa pada pembentukan kecerdasan dan pribadi Wahid Hasyim. Luas cara berpikirnya dan tidak ta'ashub dalam menghadapi suatu persoalan.

Setelah kurang lebih satu tahun di Makkah Wahid Hasyim kembali ke Indonesia. Selain sebagai seorang ulama, beliau menjadi staf pengajar di Tebuireng.

\footnotetext{
${ }^{13}$ Ruchman Basori, The Founding Father Pesantren Modern Indonesia Jejak Langkah KH. A. Wahid Hasyim, h. 60.

${ }^{14}$ Seri Buku Tempo, Wahid Hasyim untuk Republik dari Tebuirang, h. 11.

${ }^{15}$ Saifullah Ma'shum, Karisma Ulama. Kehidupan Ringkas 26 Tokoh NU (Bandung: Yayasan Bina Buana, 1998), h. 302.
} 
ISTIGHNA, Vol. 3, No 2, Juli 2020 P-ISSN 1979-2824

Homepage: http://e-journal.stit-islamic-village.ac.id/index.php/istighna

Deden Saeful Ridhwan, Novri Dewita Pendidikan Nahdlatul Ulama untuk Peradaban Dunia

(Respon K.H. Abdul Wahid Hasyim)

Beliau juga ditunjuk sebagai asisten ayahnya yang tugasnya, antara lain menjaga kesinambungan proses belajar mengajar (PBM), menjawab surat-surat yang berkaitan dengan fiqih yang ditujukan kepada ayahnya dan mendatangi pengajian atau ceramah. Hal demikian yang sudah menjadi pola kederisasi di pesantren, seorang Gus yang baru pulang dari Makkah statusnya bukan lagi menjadi santri ayahnya, tetapi sudah menjadi staf pengajar dengan berbagai tugas yang diembannya. Dengan demikian seorang Gus harus selalu siap menggantikan posisi ayahnya sebagai pemimpin pesantren.

Wahid Hasyim mengakhiri masa lajangnya pada usia 25 tahun dengan menikahi Solehah binti K.H Bisyri Syansuri pendiri dan pemimpin pesantren Denayar Jombang serta salah seorang pendiri Nahdlatul Ulama dan pernah juga menjadi Rais 'Aam PBNU. Dari buah perkawinannya melahirkan putra-putri enam orang yaitu Abdurrahman ad-Dachil (sekarang lebih dikenal dengan Abdurrahman Wahid atau Gus Dus), Aisyah, Salahuddin al-Ayyubi, Umar, Chadijah dan Hasyim.

Sayang sekali, Wahid Hasyim tidak sempat mendidik anak-anaknya lebih lama karena ia meninggal dunia dalam usia relativ muda, yaitu 39 tahun. Tepatnya beliau wafat dalam suatu kecelekaan mobil antara Cimahi dan Bandung pada tanggal 19 April 1953, dalam rangka menghadiri rapat NU di Sumedang dan dimakamkan di Samping makan ayahnya Jombang.

Bisa dibilang bahwa dari latar belakang keluarga, Wahid Hasyim adalah keturunan ulama yang sangat berpengaruh bagi dinamika perkembangan dan pertumbuhan Islam, Khususnya di pulau Jawa. Berkat kecerdasan, keuletan dan semangat yang tinggi, Wahid Hasyim menguasai ilmu pengetahuan tidak hanya ilmu pengetahuan agama tetapi juga sekuler, termasuk juga bahasa Belanda, Jepang dan Inggris.

Selagi nyantri Wahid Hasyim dikenal sebagai santri yaang amat cerdas, dan mempunyai daya hafal yang kuat. Mengenai hal ini Saifuddin Zuhri menuturkan: Aku mendengar bahwa K.H A. Wahid Hasyim dan Muhammad Ilyas ketika masih sama-sama jadi santri di Tebuireng dahulu, bukan hanya hafal seluruh bait-bait Alfiyah yang 1000 bait dengan arti dan maknanya, tetapi juga mahir menghafal dari belakang ke muka. Padahal dari muka ke belakang saja bukan main sulitnya. ${ }^{16}$

Bukti kecerdasan dan kecemerlangan pikiran Wahid Hasyim adalah sebagaimana dikisahkan oleh Ahmad Syahri sebagai berikut: "Kyai Wahid mudah menghafal nama tamu-tamunya, apalagi para pemimpin NU di daerah, lazim pada waktu itu disebut konsul sebelum ada sebutan pengurus wilayah dan cabang.

${ }^{16}$ Saifudin Zuhri, Guruku Orang-orang dari Pesantren (Yogyakarta: LKiS, 2001), h. 89. 
ISTIGHNA, Vol. 3, No 2, Juli 2020 P-ISSN 1979-2824

Homepage: http://e-journal.stit-islamic-village.ac.id/index.php/istighna

Deden Saeful Ridhwan, Novri Dewita Pendidikan Nahdlatul Ulama untuk Peradaban Dunia

(Respon K.H. Abdul Wahid Hasyim)

Kecerdasannya juga terlihat dari cara Wahid Hasyim belajar bahasa sehingga bisa menanggapi dengan baik".

Selain itu, Wahid Hasyim adalah tokoh yang sering bersilaturrahmi. Menurut Syahri kebiasaan ini dilakukan setelah jam makan siang. "Beliau menyelesaikan tugasnya sebagai Menteri Agama waktu itu belum terlalu sibuk sebagaimana Menteri Agama sekarang kemudian ke kantor PBNU melaksanakan tugas sebagai ketua umum PBNU". Kunjungan silaturrahmi kerap dilakukan kepada Muh Roem, Mohamad Natsir, Prawoto Mangkusasmito, Ir. Sukiman Wirjosandjojo dan yang lain-lain. Kunjungan juga dilakukan kepada tokoh-tokoh PNI (Partai Nasional Indonesia) seperti Moh Wilopo, Satono dan I.J. Kasimo seperti disebutkan di atas. Juga dilakukan dengan para Ulama Kyai lokal di setiap hari Jum'at sambil melaksanakan Shalat jum'at di wilayah Jakarta secara bergiliran.

Mengenai hal ini dituturkan oleh Baidowi Adnan dalam NU Online, sebutan media yang dikelola oleh PBNU di Jakarta: "kelebihan K.H Abdul Wahid Hasyim adalah gemar dan kerap bersilaturrahmi dengan berbagai kalangan, tidak terbatas kepada tokoh-tokoh NU dan Masyumi tetapi juga dengan para tokoh di luarnya. Misalnya dengan I.J Kasimo, ketua partai Katolik waktu itu. Hal ini menunjukan bahwa dia seorang tokoh yang toleran kepada agama dan idiologi yang berbeda. ${ }^{17}$

Oleh karena itu tidak heran jika pengetahuan, wawasan dan pengalamannya tak terbatas agama, golongan, yang menjadikan dia sebagai pemikir yang inklusif, egaliter diterima oleh semua pihak. Kejernihan pikirannya termanifestasi dalam kepemimpinannya baik di NU maupun ketika menjadi Menteri Agama. ${ }^{18}$

Sebelum menjabat sebagai Menteri Agama, karir Wahid Hasyim di pemerintahan diawali sebagai Menteri Negara (2 September 1945 - 14 November 1945). Pada kabinet Syahrir I dibentuklah Departemen Urusan Agama yang berada di bawah kementerian Negara. Secara resmi Kementerian Agama baru dibentuk pada kabinet Syahrir II (12 Maret 1946 - 2 Oktober 1946) dengan Menterinya H. Rasyidi. Namun secara resmi kelahiran Departemen Agama tertanggal 3 januari 1946.

Meski kementerian Agama telah didirikan sejak 3 Januari 1946, dapat dikatakan bahwa Kiayi Wahid Hasyim lah yang meletakkan fondasi kuat kementerian Agama ini hingga mampu berkembang seperti sekarang ini. Hal ini dikarenakan sampai terbentuknya Republik Indonesia Serikat (RIS) pada Desember 1949, kementerian ini lebih banyak mengurusi hal-hal yang berkaitan dengan Islam

${ }^{17}$ Baidowi Adnan, Kyai Haji Achmad Syahri, 40 Tahun Menjadi "Pemuda Roda” PBNU (Jakarta: NU Online PBNU, 2003), h. 3

${ }^{18}$ Arief Mudatsir Mandan (Ed), Napak Tilas Idham Chalid Tanggung Jawab Politik NU dalam Sejarah (Jakarta: Pustaka Indonesia Satu, 2008), h. 227. 
ISTIGHNA, Vol. 3, No 2, Juli 2020 P-ISSN 1979-2824

Homepage: http://e-journal.stit-islamic-village.ac.id/index.php/istighna

Deden Saeful Ridhwan, Novri Dewita

Pendidikan Nahdlatul Ulama untuk Peradaban Dunia

(Respon K.H. Abdul Wahid Hasyim)

secara langsung, seperti masalah nikah, talak, rujuk dan wafat. Hal ini menjadikan posisi kementerian ini waktu itu di anggap kelas dua, dibandingkan dengan kementerian lainnya. Selain itu, mengigat kondisi politik dalam negeri belum stabil, karena Belanda belum mengakui kemerdekaan RI, kementerian ini juga belum mampu mengembangkan program-programnya.

Wahid Hasyim berhasil menjalankan semua kebijakan sebagai Menteri Agama karena dua hal: pertama, adanya stabilitas negara. Pada tahun 1948 Belanda mengakui kemerdekaan, sehingga pemerintah Indonesia lebih berkonsentrasi pada penataan pemerintah dan program-programnya; Kedua, Wahid Hasyim menduduki jabatan itu dalam waktu yang relatif lama. Waktu itu suatu kabinet selalu silih berganti dalam waktu yang pendek.

\section{Karya Tulis K.H. Abdul Wahid Hasyim}

Beberapa karya tulis K.H. Abdul Wahid Hasyim yang tersebar dalam bentuk artikel, kata sambutan, pidato di berbagai mass media. Ide, gagasan dan pemikirannya sering dimuat di berbagai majalah dan Koran, dan belum sempat dibukukan. ${ }^{19}$ Dari beberapa kumpulan tulisannya dapat diklasifikasikan menjadi 9 masalah pokok yaitu: pertama, Agama. Kedua, Politik. Ketiga, Pergerakan Nasional. Keempat, Perjuangan Umat Islam. Kelima, Pendidikan dan Pengajaran. Keenam, Mistik dan Kabinet. Ketujuh, Kementerian Agama. Kedelapan, Penyelenggaraan Haji. Kesembilan, Revolusi.

Hal ini mencerminkan bahwa Kiayi Abdul Wahid Hasyim tidak sekedar leader dan organisator yang aktif di pergerakan sosial, tetapi seorang thinker yang sangat brilian diperhitungkan oleh pemikir-pemikir waktu itu. ${ }^{20}$

Meskipun karya tulisnya tidak berbentuk sebuah buku, Kiayi Wahid Hasyim dikenal sebagai seorang yang produktif menulis berbagai pandangannya tentang agama, masyarakat dan berbagai persoalan kebangsaan, terutama pada masa pergerakan nasional dan awal Indonesia merdeka. Hal itu menunjukan keluasan ilmu pengetahuannya sebagaimana dikatakan oleh Saifuddin Zuhri: ${ }^{21}$

"Tulisan-tulisannya itu melukiskan betapa jauh pandangannya ke depan serta betapa luas pengetahuannya. Ditulis dengan gaya populer, ilmiah dan dalam

${ }^{19}$ Pengakuan Abuebakar Atjek sebagai ketua pelaksana penulisan buku otobiografi Kiayi Abdul Wahid Hasyim, dalam rangka memperingati empat tahun wafatnya Kiayi Wahid Hasyim. Idenya muncul waktu Menteri Agama Masjkur menggelar upacara peringatan setahun wafatnya Kiayi Wahid Hasyim. Sehingga karya Abuebakar Atjeh ini, dipandang sebagai buku terlengkap dalam mengupas sepak terjang Kiayi Wahid Hasyim. Tempo, Wahid Hasyim untuk Republik dari Tebuirang, h. 123.

${ }^{20}$ Saiful Umam, KH. Wahid Hasyim, Konsolidasi dan Pembelaan Eksistensi, Menterimenteri Agama RI, Biografi Sosial-Politik (Jakarta: INIS, PPIM, Litbang RI, 1998), h. 84.

${ }^{21}$ Saifudin Zuhri, Guruku Orang-orang dari Pesantren, Ibid. 
ISTIGHNA, Vol. 3, No 2, Juli 2020 P-ISSN 1979-2824

Homepage: http://e-journal.stit-islamic-village.ac.id/index.php/istighna

Deden Saeful Ridhwan, Novri Dewita

Pendidikan Nahdlatul Ulama untuk Peradaban Dunia

(Respon K.H. Abdul Wahid Hasyim)

susunan gaya bahasa yang bagus sekali. Dibentangkan misalnya tentang bagaimana kedudukan kita di tengah-tengan kancah perjuangan, kemana jalan yang hendak kita tuju, manfaat apa yang bakal kita capai, tetapi juga resiko apa yang akan kita hadapi. Uraian jelas, tajam dan sangat (populis) mengesankan".

Selain itu, di sela-sela kesibukannya sebagai Menteri Agama, pengurus PBNU serta sekibukan yang lain, beliau masih sempat menulis tentang berbagai pemikiran yang sangat berguna bagi bangsa ini. Sehingga tepat sekali jika Ahmad Syahri menyebut beliau sebagai sosok Ulama intelek dan seorang pemikir sekaligus pelaksana kata Salahudin Wahid. ${ }^{22}$

\section{B. HASIL DAN PEMBAHASAN}

Sebagaimana telah dijelaskan di atas bahwa "aroma" pembaharuan yang bergema di kawasan Timur Tengah dengan tokohnya Muhammad Abduh dan Muhammad Rasyid Ridha, telah "berhembus" hingga ke bumi Nusantara, termasuk dalam dunia pendidikan. Kiayi Wahid Hasyim merupakan salah satu tokoh lokal yang membawa ide pembaharuan dalam sistem pendidikan Islam, dalam hal ini pesantren dan madrasah. ${ }^{23}$

Ide dan gagasan yang dilontarkan oleh Kiayi Wahid Hasyim tidak jarang menuai kritik bahkan penolakan dari beberapa pihak yang menganggap bahwa gagasannya tidak sesuai atau bahkan dianggap berbahaya. Hal ini disebabkan karena apa yang beliau sampaikan kadang dinilai miring dan di luar kelaziman yang ada pada saat itu.

Tanggapan yang beragam, yang pada mulanya bernada sinis dan meragukan, dari sebagian besar kelompok masyarakat, pernah juga dialami ayah beliau, Hadratussyaikh K.H. Hasyim Asy'ari. ${ }^{24}$ Sebagaimana dicatat oleh Abdurrahman

22 Senada dengan apa yang dikatakan Salahuddin Wahid (Gus Solah) ketika menilai kepribadian sang kakek Hadratus Syaikh Hasyim Asy'ari, yang menyatakan bahwa, "Mbah Hasyim Asy'ari tidak hanya pandai menulis atau berbicara tentang sejumlah prinsip utama, tetapi juga pandai menjalankan apa yang dikatakan". Nampaknya bapak dengan putranya banyak memiliki kepribadian dan kemampuan yang sama dalam prinsip hidupnya. Lihat, Salahuddin Wahid, Hadratussyaikh Komitmen Keumatan dan Kebangsaan. Dalam Zuhairi Misrawi, Hadratussyaikh Hasyim Asy'ari, Moderasi, Keumatan dan Kebangsaan (Jakarta: Kompas, 2010). h. xxii. Bandingkan dengan Munawir Sjadzali, Islam Realitas Baru dan Orientasi Masa Depan Bangsa (Jakarta: UI Press, 1993), h. 8.

${ }^{23}$ Penulis berasumsi bahwa keprihatinan Kiayi Abdul Wahid Hasyim terhadap pendidikan Indonesia terkhusus dilingkungan Pendidikan Pesantren dan Madrasah yang nota bene dimiliki masyarakat Nahdlatul Ulama, Kiayi Wahid Hasyim pernah menyatakan bahwa, "mencari seorang akademisi di dalam NU adalah ibarat mencari tukang es pada jam satu malam". Lihat, Mastuki HS., Kebangkitan Santri Cendekia, Jejak Historis, Basis Sosial dan Persebarannya (Jakarta: Pustaka Compas, 2016), h.193.

${ }^{24}$ Menurut Abdurrahman Wahid, KH. Hasyim Asy’ari termasuk satu dari beberapa "Ulama Jawi” yang memiliki nama besar yang telah mewarisi "tradisi Kurdi” dan sekaligus menyerap tradisi 
ISTIGHNA, Vol. 3, No 2, Juli 2020 P-ISSN 1979-2824

Homepage: http://e-journal.stit-islamic-village.ac.id/index.php/istighna

Deden Saeful Ridhwan, Novri Dewita

Pendidikan Nahdlatul Ulama untuk Peradaban Dunia

(Respon K.H. Abdul Wahid Hasyim)

Mas'ud, bahwa sepulang dari Makkah untuk menunaikan ibadah haji dan menuntut ilmu, Kiyai Hasyim Asy'ari memutuskan untuk mendirikan pesantren di sebuah desa terpencil dan jauh dari hiruk pikuk keramaian Tebuireng. Oleh sebagian besar kalangan, terutama para kyai pengasuh pesantren, gagasan tersebut ditertawakan karena dinilai konyol. Kritik mereka semakin tajam ketika mengetahui bahwa daerah itu tidak aman, karena banyak penduduknya yang tidak agamis, mempunyai kebiasaan sebagai perampok, pemabuk penjudi serta suka mendatangi tempattempat prostitusi. Namun waktu membuktikan bahwa keputusan Kiayi Hasyim Asy'ari tidak salah karena hingga saat ini justru Tebuireng menjadi salah satu pesantren yang cukup disegani di bumi nusantara ini. ${ }^{25}$

Model pembaharuan pendidikan Islam (pesantren dan madrasah) yang disuarakan oleh Kiayi Wahid Hasyim menyasar pada empat bentuk, yaitu: pertama, pembaharuan pada aspek institusi pendidikan, kedua, pembaharuan pada aspek isi kurikulum, ketiga, pembaharuan pada aspek metode pembelajaran, dan keempat, pembaharuan pada aspek fungsi lembaga pendidikan itu sendiri. Berikut ini akan dijelaskan beberapa aspek di atas:

\section{a. Pembaharuan Kelembagaan (Institusi)}

Model pembaharuan kelembagaan (Institusi), maksudnya yaitu pembaharuan atau perubahan lembaga yang sudah ada maupun mendirikan lembaga pendidikan Islam yang baru. Dalam konteks ini, Kiayi Wahid Hasyim mentranformasi lembaga yang sudah ada yaitu pesantren Tebuireng kemudian dimodifikasi dengan mendirikan Madrasah Nizamiyah yang dilengkapi dengan perpustakaan sebagai tempat belajar santri di luar Pesantren dan Madrasah. ${ }^{26}$

Azyumardi Azra menyatakankan bahwa dari segi proses pembaharuan pendidikan Islam ada dua model: Pertama, pembaharuan pendidikan dengan mengadopsi sistem secara menyeluruh dari sistem modern. Kedua, kelembagaan sendiri. Dalam hal ini model yang dilakukan Kiayi Wahid Hasyim adalah dengan menggunakan model kedua, di mana pesantren Tebuireng menjadi obyek dan lahirnya modifikasi Madrasah Nizamiyah.

\footnotetext{
Timur Tengah. Abdurrahman Wahid, dalam Kata Pengatar, Martin Van Bruinessen, Kitab Kuning Pesantren dan Tarekat, Tradisi-tradisi Islam di Indonesia (Bandung: Mizan, 1999), h. 13.

${ }^{25}$ Abdurrahman Mas'ud, Intelektual Pesantren (Yogyakarta: LKiS, 2004), h. 202.

${ }^{26}$ Perpustakaan zaman Islam Klasik dengan segala jenisnya, dikenal dengan beberapa nama, yaitu $D a>r$ (rumah), bayt (rumah), dan khiza>nah (gudang) yang digabungkan dengan kata al-Ilm (pengetahuan), al-Hikmah (kebijaksanaan), dan al-Kutub (buku). Perpustakaan berfungsi sebagai ruang baca, pusat aktivitas akademis, dan ruang diskusi. Di perpustakaan para santri/siswa mendapatkan keuntungan yang besar ketika belajar di perpustakaan, karena mereka dapat mengakses buku-buku dari berbagai cabang pengetahuan. George A. Makdisi, Cita Humanisme Islam Panorama Kebangkitan Intelektual dan Budaya Islam dan Pengaruhnya terhadap Renaisans Barat, h. 94. Bandingkan dengan, Antony Black, Pemikiran Politik Islam dari Masa Nabi Hingga Masa Kini (Jakarta: Serambi, 2006), h. 66.
} 
ISTIGHNA, Vol. 3, No 2, Juli 2020 P-ISSN 1979-2824

Homepage: http://e-journal.stit-islamic-village.ac.id/index.php/istighna

Deden Saeful Ridhwan, Novri Dewita

Pendidikan Nahdlatul Ulama untuk Peradaban Dunia

(Respon K.H. Abdul Wahid Hasyim)

Model pembaharuan yang dilakukan Kiayi Wahid Hasyim ini merupakan nama intitusi pendidikan yang dibangun oleh pemimpin Saljuk, Nizam al-Mulk pada tahun 1064/1092 sebagai inspirasinya. ${ }^{27}$ Kiayi Wahid Hasyim memandang bahwa terbatasnya mata pelajaran yang diberikan di pesantren, membuat santri sulit bersaing dengan temannya yang belajar dengan menggunakan sistem pendidikan Barat. Kelemahan santri, menurutnya, adalah kurangnya penguasaan terhadap ilmu-ilmu Barat (sekuler), Bahasa Asing dan keterampilan. ${ }^{28}$ Dengan dibekali beberapa keterampilan. Dengan demikian diharapkan para santri mampu bersaing untuk memperebutkan posisi dan peran penting di masyarakat sebagaimana lulusan lembaga pendidikan umum.

Untuk menentukan tipe sekolah apa yang dijadikan model bagi Madrasah Nizamiyah, Abu Bakar Atjeh menginformasikan bahwa model yang dikembangkan adalah kreasi Kiayi Wahid Hasyim sendiri. Hal ini dikarenakan tidak ada kemiripan tipe Madrasah yang dibangun di Indonesia, sebelum berdirinya Madrasah Nizamiyah.

Meskipun menggunakan nama Nizamiyah sebagaimana model institusi yang pernah didirikan oleh pemimpin Saljuk, Nizam al-Mulk (485/1092), yaitu Madrasah Nizamiyah di Baghdad. Namun, asumsi penulis, hanya sebatas simbol atau pada namanya saja, karena dalam kenyataanya keduanya mempunyai perbedaan yang cukup signifikan. Madrasah Nizamiyah di Baghdad hanya mengajarkan ilmu agama saja, sedangkan Madrasah Nizamiyah yang digagas Kiayi Wahid Hayim secara substantif adalah memadukan antara belajar agama dan belajar umum dan juga keterampilan, bahkan juga disediakan berbagai fasilitas pendidikan, termaksuk di antaranya perpustakaan.

Dari uraian di atas, dapat dikatakankan bahwa, model pembaharuan pesantren dan madrasah yang digagas Kiayi Abdul Wahid Hasyim adalah dengan cara pembaharuan aspek kelembagaan, isi, metodologi dan fungsi lembaga pesantren dan madrasah. Sedangkan model yang diambil adalah mengembangkan sistem dan lembaga yang dimilikinya, bukan dengan cara mengadopsi sitem pendidikan Barat secara keseluruhan.

\section{b. Konten Kurikulum}

27 Pendidikan formal Islam baru muncul pada masa lebih belakangan, yakni dengan kebangkitan madrasah. Secara tradisional sejarawan pendidikan Islam, seperti Munir ud-Din Ahmed, George Makdisi, Ahmad Syalabi dan Michael Stanton menganggap, bahwa madrasah pertama didirikan oleh Wazir Nizham al-Mulk, madrasah ini kemudian terkenal sebagai Madrasah Nizham al-Mulk. Lihat. Azyumardi Azra, Pendidikan Islam Tradisi dan Modernisasi Menuju Milenium Baru (Jakarta: Kalimah, 2001), h. viii.

${ }_{28}$ Abu Bakar Atjeh, Sejarah Hidup KH. Wahid Hasyim dan Karang Tersiar (Jakarta: Panitia Buku Peringatan alm. KH. A. Wahid Hasyim, 1957), h. 151. 
ISTIGHNA, Vol. 3, No 2, Juli 2020 P-ISSN 1979-2824

Homepage: http://e-journal.stit-islamic-village.ac.id/index.php/istighna

Deden Saeful Ridhwan, Novri Dewita

Pendidikan Nahdlatul Ulama untuk Peradaban Dunia

(Respon K.H. Abdul Wahid Hasyim)

Pembahasan tentang kurikulum bisa kita temukan dari beberapa sumber, bahwa kurikulum dapat dimaknai dalam tiga konteks, pertama, kurikulum sebagai sejumlah mata pelajaran, kedua, kurikulum sebagai pengalaman belajar, ketiga, kurikulum sebagai perencanaan program belajar. $^{29}$

Dalam kontek kurikulum pesantren di sini dimaknai sebagai seperangkat rencana dan pengaturan komponen-komponen pendidikan dan pengajaran yang sistematis, yang meliputi baik pada level tujuan, isi, organisasi maupun pada level strategis, yang digunakan sebagai pedoman penyelenggaraan Kegiatan Belajar Mengajar (PBM) pada lembaga yang bersangkutan, untuk mencapai tujuan pendidikan tertentu. Komponenkomponen tersebut saling mendukung dan membentuk satu kesatuan yang tak terpisahkan. ${ }^{30}$ Steenbrink mengklasifikasikan tiga kelompok mata pelajaran di pesantren: Pertama, bidang teknis, yaitu fiqh, ilmu tafsir, mawaris, ilmu falaq dan sebagainya. Kedua, bidang hafalan, yaitu pelajaran al-Qur'an, ilmu Bahasa Arab dan. Ketiga, ilmu yang bersifat membina emosi keagamaan seperti aqidah, tasawuf dan akhlaq.

Di tingkat awal, santri biasanya menggeluti bidang hafalan. Membaca al-Qur'an adalah materi pertama di pesantren, ${ }^{31}$ meskipun tidak sampai pada tahap pendalaman dan pemahaman. Dalam tahap ini biasanya santri baru diajarkan oleh santri senior yang menjadi badal (wakil) pengasuh pesantren. Apabila ia telah dianggap mampu dalam level ini, maka ia diizinkan mengikuti pengajian ilmu Bahasa Arab; nahwu (sintaksis) dan sharaf (morfologi). Ilmu bahasa dipelajari di masa awal dimaksudkan sebagai pengetahuan dan kemampuan dasar bagi santri untuk dapat dipergunakan pada tahap pelajaran tingkat lanjut. Diversifikasi bidang garap ilmu pesantren yang beragam menunjukkan ketidaksamaan panjangnya waktu yang

29 Wina Sanjaya, Pembelajaran dalam Implementasi Kurikulum Berbasis Kompetensi (Jakarta: Kencana, 2005), h. 2-3.

${ }^{30}$ Pasal 1 Undang-undang Sistem Pendidikan Nasional NO. 20 Tahun 2003. Lihat juga, Galen Saylor J., Alexander, William M, and Lewis Arthur J., Curriculum Planning for Better Teaching and Learning (Holt-Rinehart and Winston, 1981), h. 2. Bandingkan dengan Abdullah Syukri Zarkasyi, Manajemen Pesantren Pengalaman Pondok Modern Gontor (Ponorogo: Trimurti Press, 2005), h. 144.

${ }^{31}$ Ada dua bentuk hafalan, yaitu hafalan yang terbatas hanya dengan cara memindahkan bahwa bacaan ke dalam ingatan, sebagaimana yang umumnya dilakukan oleh para ahli hadis dan ahli leksikografi. Sedangkan hafalan bentuk kedua biasanya dilakukan oleh para sastrawan dan kaum skolastik yang menghendaki pemahaman yang lebih baik terhadap suatu bahan. Untuk lebih jelasnya tentang peran metode hafalan dalam transformasi pengetahuan. Lihat, Goerge A. Makdisi, Cita Humanisme Islam, Panorama Kebangkitan Intelektual dan Budaya Islam dan Pengaruhnya terhadap Renaissans Barat (Jakarta: Serambi, 2005), h. 315-325. 
ISTIGHNA, Vol. 3, No 2, Juli 2020 P-ISSN 1979-2824

Homepage: http://e-journal.stit-islamic-village.ac.id/index.php/istighna

Deden Saeful Ridhwan, Novri Dewita

Pendidikan Nahdlatul Ulama untuk Peradaban Dunia

(Respon K.H. Abdul Wahid Hasyim)

dimintakan bagi pengajian ilmu-ilmu ini. ${ }^{32}$ Pada pesantren kecil yang lebih menekankan pembinaan mental sosial, umpamanya, pelajaran nahwu tidak dimaksudkan mencapai tingkat mahir dan mendalam. Kitab sumbernya paling-paling kitab tipis, seperti: al-Jurumiyyah, al-Mutamimmah. Sementara kitab selanjutan, seperti Nazam al-Imriti, Milhat al-I'rab atau sampai alfiyah dan syarah Ibnu 'Aqil hanya diajarkan di pesantren yang lebih besar dan biasanya yang mengambil spesialis disiplin ilmu alat. ${ }^{33}$

Melihat kurikulum yang demikian, di mana pesantren dan madrasah yang hanya belajar ilmu-ilmu keagamaan, ${ }^{34}$ Kiayi Wahid Hasyim, meskipun tidak pernah mengenyam pendidikan Barat modern, memperkenalkan ilmuilmu umum (sekuler) hal ini disebabkan atas dasar asumsi beliau bahwa dalam beberapa hal, pesantren tidak sesuai lagi dengan perkembangan dan tuntunan zaman sehingga sangat membutuhkan pembaharuan. ${ }^{35}$

Untuk merealisasikan gagasan beliau itulah maka Madrasah Nizamiyah didirikan dengan memasukan pembelajaran umum selain materi agama sebagaimana madrasah pada umumnya saat itu. Pelajaran umum yang diajarkan di Madrasah Nizamiyah adalah aritmatika, sejarah, geografi dan ilmu pengetahuan alam, kemudian santri diberi tambahan pelajaran bahasa, yakni Indonesia, Inggris dan Belanda. Keterampilan mengetik juga diberikan untuk meningkatkan kualitas keterampilan santri. ${ }^{36}$ Materi-materi tersebut merupakan titik lemah alumni madrasah sehingga menyebabkan mareka bersaing dengan alumni pendidikan Barat.

Sebagaimana implementasinya, para santri (dan atau siswa madrasah) tidak hanya dibekali ilmu-ilmu agama sebagai bekal di akhirat kelak, namun juga dibekali "alat" untuk hidup di dunia berupa materi kurikulum yang komprehensif yang berfungsi memberdayakan kemampuan head (pikiran), heath (perasaan) dan hand (keterampilan). Dalam istilah sekarang dibekali dengan kecerdasan emosional dan kecerdasan kinestetikal (keterampilan).

32 Abdurrahman Wahid, Pesantren Sebagai Sub Kultur. Dalam M. Dawam Rahardjo (Ed): Pesantren dan Pembaharuan (Jakarta: LP3ES, 1983), h. 40-43. Lihat juga, Qowaid, Diversifikasi Pendidikan Islam (Jakarta: Pesagimandiri Perkasa, 2019), h. 2.

${ }^{33}$ Ahmad Ismail Outhman, Dari Mengaji ke Mengkaji, dalam Abdul Khaliq (Ed), Dinamika Pesantren dan Madrasah (Yogyakarta: Pustaka Pelajar, 2002), h. 72-83.

34 Pada hakikatnya pendidikan keagamaan Islam merupakan pendidikan yang mempersiapkan peserta didik/santri untuk dapat menjalankan peranan yang menuntut kepada tingkat penguasaan pengetahuan yang berkaitan dengan ajaran agama Islam dan/atau menjadi ahli ilmu agama Islam dan mengamalkan ajaran-ajaran agama Islam dalam kehidupan sehari-hari. Lihat, Abd Muin M, Praktek Pendidikan Keagamaan di Indonesia, (Ed). Deden Saeful Ridhwan (Jakarta: Pesagimandiri Perkasa, 2019), h. 9. Lihat juga, Peraturan Menteri Agama RI No. 13 Tahun 2014. Tentang Pendidikan Keagamaan Islam, Pasal 2.

${ }^{35}$ Badri Yatim dkk, Sejarah Perkembangan Madrasah (Jakarta: DEPAG RI, 2002), h. 72-

${ }^{36}$ Zamakhsyari Dhofier, Tradisi Pesanten Studi tentang Pandangan Hidup Kyai, h. 115 
ISTIGHNA, Vol. 3, No 2, Juli 2020 P-ISSN 1979-2824

Homepage: http://e-journal.stit-islamic-village.ac.id/index.php/istighna

Deden Saeful Ridhwan, Novri Dewita Pendidikan Nahdlatul Ulama untuk Peradaban Dunia

(Respon K.H. Abdul Wahid Hasyim)

Sulthon Mashud, menyebutkan beberapa langkah yang harus dilakukan dalam hal ini, antara lain; ${ }^{37}$

1) Melakukan kajian kebutuhan (need assessment) untuk mengetahui faktor penentu kurikulum serta latar belakang.

2) Menentukan mata pelajaran yang akan diajarkan.

3) Merumuskan tujuan pembelajaran.

4) Menentukan hasil belajar yang diharapkan dari santri.

5) Merumuskan topik dan tema setiap mata pelajaran.

6) Menentukan syarat-syarat yang harus dipenuhi peserta didik (sanrti).

7) Menentukan strategi mengajar yang serasi, efisien dan efektif serta menyediakan alat peraga dan sumber belajar.

8) Menentukan alat evaluasi hasil belajar dan skala penilaiannya.

9) Membuat rancangan rencana penilaian kurikulum secara menyeluruh dan strategi perbaikannya.

Tanpaknya, langkah-langkah yang harus ditempuh memang demikian komplek, akan tetapi memang demikianlah yang harus dilalui jika menginginkan tujuna pembelajaran (dalam skala mikro) dan tujuan pendidikan (dalam skala yang lebih luas) akan tercapai. Namun demikian, dalam pelaksanaannya juga mempertimbangkan kondisi dan situasi yang ada pada masing-masing pesantren atau madrasah yang bersangkutan.

\section{c. Metode Pembelajaran}

Sebagaimana diungkapkan oleh banyak tokoh bahwa metode pembelajaran di pesantren (terutama pesantren salaf) menggunakan sistem sorogan dan bandongan. ${ }^{38}$

Metode semacam itulah yang ingin diperbaharui oleh Kiayi Wahid Hasyim, metode pengajaran yang selama ini diterapkan dianggap kurang relevan. Metode bandongan dipandang sangat tidak efektif untuk mengembangkan inisiatif santri. Santri datang hanya mendengarkan, menulis, dan menghafal pelajaran yang diberikan, tanpa ada kesempatan mengajukan pertanyaan atau bahkan mendiskusikan pelajaran, Kiayi Wahid Hasyim secara jelas meyebutkan bahwa metode bandongan membuat santri pasip. ${ }^{39}$ Ia mengajukan beberapa usulan pembaharuan, di antaranya metode yang digunakan dalam proses belajar mengajar (PBM), tujuan atau harapan santri belajar di pesantren dan pengalaman mata pelajaran Barat.

\section{$79-80$}

${ }^{37}$ Sulthon Masyhud dkk, Manajemen Pondok Pesantren (Jakarta: Diva Pustaka 2005), h.

38 A. Helmy Faisal Zaini, Pesantren Akar Pendidikan Islam Nusantara (Jakarta: Perhimpunan Pengembangan Pesantren dan Masyarakat (P3M), 2015), h. 45.

${ }^{39}$ Ahmad Zaini, Kiayi Haji Abdul Wahid Hasyim Beberapa Pemikiran Pembaruan, dalam. Tempo, Wahid Hasyim untuk Republik dari Tebuireng (Jakarta: Kompas, 2011), h. 127. 
ISTIGHNA, Vol. 3, No 2, Juli 2020 P-ISSN 1979-2824

Homepage: http://e-journal.stit-islamic-village.ac.id/index.php/istighna

Deden Saeful Ridhwan, Novri Dewita Pendidikan Nahdlatul Ulama untuk Peradaban Dunia

(Respon K.H. Abdul Wahid Hasyim)

Kiayi Wahid Hasyim ingin menciptakan suatu kondisi belajar yang memberikan ruang dan kesempatan kepada santri untuk mengungkapkan pikiran, gagasan, pendapat bahwa kritikannya terhadap suatu materi pembelajaran yang mereka peroleh dari sang guru.

Di sini nampak kekritisan santri mendapatkan apresiasi dari Kiayi Wahid Hasyim. Menurut Ahmad Ismail, pengetahuan kritisme berfikir dan logika baru diperoleh santri di tahun kelima belajar di pesantren, ketika mereka diajarkan ilmu mantiq. Tragisnya, kesempatan itu kurang dimanfaatkan untuk menghasilkan suatu pengetahuan dan terutama kesadaran optimal bagi pentingnya berfikir kritis. Banyak yang melatarbelakanginya, beberapa diantaranya adalah keterbatasan kemampuan dan wawasan filosofis, minimnya kitab rujukan yang tersedia, konsentrasi yang masih terpecah oleh bahasa pengantar buku yang dipelajarinya (biasanya bahasa Arab) dan lain-lain, sehingga pengupasan masalah bahasa sebagai media penyampai pesan bermasalah menyita waktu yang disediakan.

Selain itu semua, pengajian-pengajian yang diselenggarakan memang kurang memberikan porsi yang banyak bagi pembiasaan berfikir kritis. Hafalan dan menelaah teori-teori, qaul-qaul, dan produk hukum yang sudah matang merupakan menu harian, sehingga terpantul bahkan ditinggkatkan sanrti senior yang menyelenggarakan diskusi panel, bahtsul masail tingkat menengah (wustha) pun masih lebih suka mencari dan kemudian mengamini pendapat dan qaul para ulama salaf mengenai itu dan mencari apa yang membuat mereka berpendapat seperti itu.

Demikianlah, kondisi pesantren pada umumnya, sehingga Kiayi Wahid Hasyim tidak begitu senang dengan budaya tersebut. Kiayi Wahid Hasyim mengharapkan terjadi suatu proses belajar mengajar yang dialogis, di mana posisi guru bukan lagi sebagai satu-satunya sumber belajar, pendapat guru bukanlah kebenaran mutlak sehingga dapat dipertanyakan bahkan ditambah oleh santri. Selain itu, proses belajar mengajar berorientasi pada murid sehingga potensi yang dimilikinya akan terwujud dan ia akan menjadi dirinya sendiri. Sehingga santri bukan hanya menjadi objek pendidikan, namun juga sekaligus subyek pendidikan itu sendiri. Sementara guru hanya memposisikan dirinya sebagai motivator, mediator serta fasilitator dalam proses pembelajaran.

\section{d. Fungsi Lembaga Pendidikan}

Shipman dalam bukunya "Education and Modernization' sebagaimana dikutip Azra, mengungkapkan bahwa fungsi pokok pendidikan dalam masyarakat modern terdiri dari tiga bagian, pertama, sebagai lembaga sosialisasi. Pendidikan adalah wahana bagi integrasi peserta didik ke dalam nilai-nilai kelompok atau nasional yang dominan. kedua, lembaga 
ISTIGHNA, Vol. 3, No 2, Juli 2020 P-ISSN 1979-2824

Homepage: http://e-journal.stit-islamic-village.ac.id/index.php/istighna

Deden Saeful Ridhwan, Novri Dewita Pendidikan Nahdlatul Ulama untuk Peradaban Dunia

(Respon K.H. Abdul Wahid Hasyim)

penyekolahan (schooling), mempesiapkan peserta didik untuk menduduki posisi sosial-ekonomi tertentu dan, oleh karena itu, penyekolahan harus membekali peserta didik dengan kualifikasi-kualifikasi pekerjaan dan profesi yang akan membuat mereka mampu memainkan peran dalam masyarakat. Sedangkan dalam fungsi ketiga, pendidikan (education) untuk menciptakan kelompok elit yang pada gilirannya akan memberikan sumbangan besar bagi kelanjutan program modernisasi. ${ }^{40}$

Berangkat dari kerangka teoritis di atas Kiayi Wahid Hasyim melakukan beberapa langkah dalam kaitannya dengan fungsi lembaga. Sejumlah gagasan tentang pendidikan agama yang selama ini tertahan dalam benaknya lantas mengalir deras, saat menjadi Menteri Agama. Kiayi Wahid Hasyim mengeluarkan peraturan pemerintah pada 20 Januari 1950 yang mewajibkan pendidikan dan pengajaran agama di lingkungan sekolah umum sebagai bagian dari kurikulum pendidikan nasional baik negeri maupun swasta. Dalam pandangannya, sejak kolonialis Belanda yang mengarahkan dan mengadopsi sistem Barat yang sekuler, banyak hal yang hilang dari sistem pendidikan nasional, yakni nilai dan moral.

Selanjutnya Kiayi Wahid Hasyim mengatur ihwal pendirian sekolah guru dan Hakim Agama di beberapa kota. Pendirian pendidikan guru agama berangkat dari pemikirannya bahwa guru yang mengajar di madrasah hanya lulusan 'Hollandsche Inlandsche School' atau pesantren, sehingga dinilai masih kurang ilmunya untuk menjadi guru agama di setiap provinsi dan kabupaten memiliki arti penting, "memberi epek samping" kualitas lulusan madrasah menjadi lebih baik. Banyak santri yang akhirnya menjadi pegawai kantor Urusan Agama, ketika Kiayi Wahid Hasyim menjabat sebagai menteri Agama RI. Hal ini tidak lepas dari jerih payah Kiayi Wahid Hasyim ketika merencanakan kurikulum pesantren dan madrasah yang mengajarkan membaca dan menulis huruf latin, juga bahasa sebagai alat komunikasinya.

Berikutnya tentang fungsi lembaga pendidikan dalam hal ini perguruan tinggi menurutnya bahwa pembentukan perguruan tinggi bertujuan untuk mencapai kemajuan dengan penekanan pada pengembangan atmosfer berfikir secara rasional. ${ }^{41}$

${ }^{40}$ Azyumardi Azra, Pendidikan Islam Tradisi dan Modernisasi Menuju Milenium Baru (Jakarta: Kalimah, 2001), h. 32. Lihat juga, Mahmud Arif, Pendidikan Islam Transformatif (Jogjakarta: LKiS, 2008), h. 130.

${ }^{41}$ Tempo, Wahid Hasyim untuk Republik dari Tebuireng (Jakarta: Kompas, 2011), h. 79. 
ISTIGHNA, Vol. 3, No 2, Juli 2020 P-ISSN 1979-2824

Homepage: http://e-journal.stit-islamic-village.ac.id/index.php/istighna

Deden Saeful Ridhwan, Novri Dewita Pendidikan Nahdlatul Ulama untuk Peradaban Dunia

(Respon K.H. Abdul Wahid Hasyim)

\section{KESIMPULAN}

Kiayi Wahid Hasyim seorang reformis properubahan, ia mengajukan gagasan perubahan sekaligus melakukan yang sama sekali asing bagi lingkungan pesantren. Perubahan paling monumental di Pondok Pesantren Tebuireng, beberapa pembaharuan dalam metode serta tujuan belajar di pesantren dan pendirian madrasah. Kiayi Wahid Hasyim menjadikan sistem tutorial, sebagai pengganti metode bandongan. Menurutnya metode bandongan sangat tidak efektif untuk mengembangkan inisiatif para santri.

Sedikit sekali yang kemudian menyadari bahwa Kiayi Wahid Hasyim seorang tradionalis yang berpikiran futuristik. Ia adalah sosok yang mewakili kalangan yang jarang sekali tersentuh oleh para akademisi bahkan peneliti sekalipun, yang kebanyakan para peneliti terutama peneliti Barat, cenderung jatuh hati pada kelompok modernis yang dianggap dinamis, adaptif, pragmatis, dan sama sekali tidak bermusuhan dengan yang berasal dari kawasan Barat.

\section{REFERENSI}

Adnan, Baidowi, Kyai Haji Achmad Syahri, 40 Tahun Menjadi "Pemuda Roda" PBNU (Jakarta: NU Online PBNU, 2003)

Ali, Fachry dan Bakhtiar Effendy, Merambah Jalan Baru Islam, Rekonstruksi Pemikiran Islam Indonesia Masa Orde Baru (Bandung: Mizan, 1990), h. 48.

Arif, Mahmud, Pendidikan Islam Transformatif (Jogjakarta: LKiS, 2008)

Azra, Azyumardi, Pendidikan Islam Tradisi dan Modernisasi Menuju Milenium Baru (Jakarta: Kalimah, 2001)

Atjeh, Abu Bakar, Sejarah Hidup KH. Wahid Hasyim dan Karang Tersiar (Jakarta: Panitia Buku Peringatan alm. KH. A. Wahid Hasyim, 1957)

Basori, Ruchman, The Founding Father Pesantren Modern Indonesia Jejak Langkah KH. A. Wahid Hasyim (Jakarta: Incies, 2008)

Bruinessen, Martin Van, Kitab Kuning Pesantren dan Tarekat, Tradisi-tradisi Islam di Indonesia (Bandung: Mizan, 1999)

Black, Antony, Pemikiran Politik Islam dari Masa Nabi Hingga Masa Kini (Jakarta: Serambi, 2006)Daulay,

Dhofier, Zamakhsyari, Tradisi Pesantren. Studi Pandangan Hidup Kiayi dan Visinya Mengenai Masa Depan Indonesia (Jakarta: LP3ES, 2011)

--------, K.H. A Wahid Hasyim Rantai Penghubung Peradaban Pesantren dengan Peradaban Indonesia Modern (Jakarta: Prisma No. 8, 1984)

Galen Saylor J., Alexander, William M, and Lewis Arthur J., Curriculum Planning for Better Teaching and Learning (Holt-Rinehart and Winston, 1981) 
ISTIGHNA, Vol. 3, No 2, Juli 2020 P-ISSN 1979-2824

Homepage: http://e-journal.stit-islamic-village.ac.id/index.php/istighna

Deden Saeful Ridhwan, Novri Dewita Pendidikan Nahdlatul Ulama untuk Peradaban Dunia

(Respon K.H. Abdul Wahid Hasyim)

Haidar Putra, Pendidikan Islam dalam Perspektif Filsafat, (Jakarta: Kharisma Putra Utama, 2014)

Haroen, A. Musthofa, Meneguhkan Islam Nusantara, Biografi Pemikiran dan Kiprah Kebangsaan Prof. Dr. KH. Said Aqil Siroj, MA. (Jakarta: Khalista, 2015)

Madjid, Nurcholis, Bilik-bilik Pesantren sebuah Potret Perjalanan (Jakarta: Paramadina, 1997)

Mas'ud, Abdurrahman, Intelektual Pesantren (Yogyakarta: LKiS, 2004)

Makdisi, Goerge A., Cita Humanisme Islam, Panorama Kebangkitan Intelektual dan Budaya Islam dan Pengaruhnya terhadap Renaissans Barat (Jakarta: Serambi, 2005)

Masyhud, Sulthon dkk, Manajemen Pondok Pesantren (Jakarta: Diva Pustaka 2005)

Ma'shum, Saifullah, Karisma Ulama. Kehidupan Ringkas 26 Tokoh NU (Bandung: Yayasan Bina Buana, 1998)

Mastuki HS., Kebangkitan Santri Cendekia, Jejak Historis, Basis Sosial dan Persebarannya (Jakarta: Pustaka Compas, 2016)

Mandan, Arief Mudatsir (Ed), Napak Tilas Idham Chalid Tanggung Jawab Politik NU dalam Sejarah (Jakarta: Pustaka Indonesia Satu, 2008)

Misrawi, Zuhairi, Hadratussyaikh Hasyim Asy'ari, Moderasi, Keumatan dan Kebangsaan (Jakarta: Kompas, 2010)

Muin M., Abd, Praktek Pendidikan Keagamaan di Indonesia, (Ed). Deden Saeful Ridhwan (Jakarta: Pesagimandiri Perkasa, 2019)

Outhman, Ahmad Ismail, Dari Mengaji ke Mengkaji, dalam Abdul Khaliq (Ed), Dinamika Pesantren dan Madrasah (Yogyakarta: Pustaka Pelajar, 2002)

Peraturan Menteri Agama RI No. 13 Tahun 2014. Tentang Pendidikan Keagamaan Islam, Pasal 2.

Pranowo, Bambang, Runtuhnya Dikotomi Santri-Abangan, Refleksi Sosiologis atas Perkembangan Islam di Jawa Pasca 1965. Dalam Pidato Pengukuhan Guru Besar dalam Ilmu Sosiologi Agama pada Fakultas Ushuluddin IAIN Syarif Hidayatullah Jakarta (Jakarta: IAIN, 2001)

Qowaid, Diversifikasi Pendidikan Islam (Jakarta: Pesagimandiri Perkasa, 2019)

Rahardjo, M. Dawam (Ed): Pesantren dan Pembaharuan (Jakarta: LP3ES, 1983)

Ridhwan, Deden Saeful, Madrasah di Indonesia, Dinamika dan Eksistensinya, (Jakarta: Jurnal Ma'arif NU, 2017), Edisi XV. Tahun 2017.

Rumadi, Post Tradisionalisme Islam Wacana Intelektualisme dalam Komunitas $N U$ (Jakarta: Departemen Agama RI, 2007) 
ISTIGHNA, Vol. 3, No 2, Juli 2020 P-ISSN 1979-2824

Homepage: http://e-journal.stit-islamic-village.ac.id/index.php/istighna

Deden Saeful Ridhwan, Novri Dewita Pendidikan Nahdlatul Ulama untuk Peradaban Dunia

(Respon K.H. Abdul Wahid Hasyim)

Saifuddin, Lukman Hakim, Kekhasan Pendidikan Islam (Jakarta: Direktorat Jenderal Pendidikan Islam Kemterian Agama RI, 2015)

Seri Buku Tempo, Wahid Hasyim untuk Republik dari Tebuirang (Jakarta: KPG, 2011)

Sjadzali, Munawir, Islam Realitas Baru dan Orientasi Masa Depan Bangsa (Jakarta: UI Press, 1993)

Sanjaya, Wina, Pembelajaran dalam Implementasi Kurikulum Berbasis Kompetensi (Jakarta: Kencana, 2005)

Tim Penyusun Kamus Besar Bahasa Indonesia, Kamus Besar Bahasa Indonesia (Jakarta: Balai Pustaka, 1988)

Umam, Saiful, KH. Wahid Hasyim, Konsolidasi dan Pembelaan Eksistensi, Menteri-menteri Agama RI, Biografi Sosial-Politik (Jakarta: INIS, PPIM, Litbang RI, 1998)

Undang-undang RI No 20 Tahun 2003 tentang Sistem Pendidikan Nasional (Bandung: Citra Umbara, 2016)

Yatim, Badri dkk, Sejarah Perkembangan Madrasah (Jakarta: DEPAG RI, 2002)

Zarkasyi, Syukri, Manajemen Pesantren Pengalaman Pondok Modern Gontor (Ponorogo: Trimurti Press, 2005)

Zaini, A. Helmy Faisal, Pesantren Akar Pendidikan Islam Nusantara (Jakarta: Perhimpunan Pengembangan Pesantren dan Masyarakat (P3M), 2015)

-------, A. Helmy Faisal, Nasionalisme Kaum Sarungan (Jakarta: Kompas, 2018)

Zuhri, Saifudin, Guruku Orang-orang dari Pesantren (Yogyakarta: LKiS, 2001) 